\title{
Pemilihan Supplier Kulit dan Kelayakan Efesiensi Usaha di Fajar Shoes Menggunakan Analytical Network Proces (ANP) dan Nilai Tambah Hayami
}

\author{
Ujang Cahyadi $^{1}$, Encep Jianul Hayat ${ }^{2}$, Moch Dicky Riswandi ${ }^{3}$ \\ Jurnal Kalibrasi \\ Institut Teknologi Garut \\ Jl. Mayor Syamsu No.1 Jayaraga Garut 44151 Indonesia \\ Email: jurnal@itg.ac.id \\ ${ }^{1}$ ujang.cahyadi@itg.ac.id \\ 2encepjian@itg.ac.id \\ 31703053@itgarut.ac.id
}

\begin{abstract}
Abstrak - Meningkatnya permintaan sepatu kulit di Fajar Shoes pada saat ini membuat para supplier mengalami peningkatan karena bahan baku utamanya yaitu kulit. Dengan adanya komitmen kerjasama anatara pemilik Fajar Shoes dengan supplier untuk memberikan kualitas kulit yang bagus dengan harga terjangkau, sehingga Fajar Shoes dan supplier saling menguntungkan. Dengan tujuan pelenitian ini yaitu untuk menganalisis efisiensi usaha. Penelitian ini menggunakan metode $\mathrm{R} / \mathrm{C}$ ratio. NVP, BEP kelayakan usaha dan hayami untuk menentukan nilai tambah. Hasil penelitian ini yaitu Fajar Shoes dengan jumlah tenaga kerja 6 orang dengan nilai tambah yang didapatkan dari produksi sepatu kulit sebesar Rp. 2.523.346, Ratio 74\% sebesar Rp. 2.306.000 bisa dikategorikan sebagai npv lalu nilai BEP berdasarkan rupiah sebesar Rp. 26.137.557 dan berdasarkan unit 105 penjualan sepatu kulit selama satu bulan. Maka usaha sepatu kulit ini sudah efisien dan penelitian ini bertujuan untuk memilih dan menentukan supplier yang terbaik dan sesuai kebutuhan perusahaan, metode yang digunakan untuk memilih supplier yaitu metode analyrical network process. Dimana metode anp ini digunakan untuk menentukan hasil dari setiap kriteria dan merangking alternatif yang terpilih. Penelitian ini dilakukan di Fajar Shoes. Sumber data analisis ini diperoleh dengan cara wawancara dan kuisioner pada responden, responden ini terdiri dari pemilik perusahaan dan dapat hasil penelitian pertama menunjukan dalam pemilihan supplier ada empat kriteria diantaranya ada kualitas, harga, kuantitas, pengiriman, tujuh subkriteria dan tiga supplier digunakan diantaranya bongsor leather, abadi leather dan perkasa leather. Pada tahapan pertama yang dilakukan peneliti ini adalah mentukan hasil dari setiap kriteria. Dengan anp terpilih kriteria pertama ialah kriteria kualitas, kriteria kedua yaitu kriteria harga, ketiga kriteria kuantitas dan ke empat kriteria pengiriman, selanjutnya perhitungan menggunakan anp untuk alternatif supplier yang terpilih yaitu bongsor leather. Kemudian melakukan perhitungan menggunakan metode nilai tambah (hayami) untuk menganalisis keuntung UMKM Fajar Shoes.
\end{abstract}

Kata Kunci - Analytical Network Process; Dan Nilai Tambah (Hayami); NVP.

\section{PENDAHULUAN}

Fajar Shoes merupakan sebuah usaha umkm mikro yang terletak di Jln. Ahmad Yani Timur Karangpawitan, Ciparay No. 53 Industri ini memproduksi sepatu yang berbahan dasar kulit. Persaingan dalam segi jual atau bisnis menjadi semakin ketat [1]. Usaha kecil dan menengah (UMKM) adalah aspek yang mengubah dampaknya terhadap perekonomian masyrakat indonesia. Seiring berkembangnya usaha kecil dan menengah pada saat ini maka persaingan dalam segi jual atau bisnis menjadi semakin ketat. Salah satu persaingan di industri sepatu kulit. Menurut (rukmini, 2018) untuk dapat memperoleh kemenangan dalam persaingan di industri ini maka suatu perusahaan harus memberikan produk yang bagus dan modern serta memuwujud kan 
seleresa keinginan konsumen yang selalu berubah-ubah dan perusahaan wajib berarti memilih Supplier bahan baku yang bisa memenuhi kebutuhan industri yang cocok dengan kualitas yang sudah ditentukan serta waktu yang sudah ditentukan siklus hidup produk yang semakin terus berubah, serta harga terus menaik dan tidak signifikan [2]. Keseimbangan nilai tambah ini dapat dijadikan kebijakan untuk menetapkan harga yang stabil untuk komoditas gambir dengan tujuan mempertahankan keberlangsungan bisnis gambir di sumatera barat (Hendra saputra 2018). untuk mengetahui keseimbangan nilai tambah yang diperoleh setiap pelaku rantai pasok menggunakan metode hayami termodifikasi untuk menghitung nilai tambah dan analytical network

process untuk menganalisis tingkat risiko pada pelaku rantai pasok gambir ( Mahendra 2018 ). [3] beberapa penelitian yang telah dilaksanakan mengenai pemilihan supplier yang berujudul "penerapan analytic network process (anp) sebagai sistem pendukung keputusan dalam pemberian tesis" tahun 2017. Peneltian ini dilakukan oleh (tri ajeng 2017) dengan menggunakan metode anp untuk mendapatkan supplier dan kriteria yang terbaik. Adapun penelitian lainnya juga terdapat menggunakan metode anp dan hayami yang melakukan penelitianya yaitu (hendra 2018) dengan judul "Nilai Tambah yang Adil pada Pelaku Rantai Pasok Gambir di Sumatera Barat". perbedaan dengan penelitian yang dilaksanakan yaitu dari metode yang digunakan nya baru agar relevan terhadap pemilihan supplier nya [4] dasar dari pemilihan metode ini yaitu karena metode ANP yaitu akan mampu memutuskan sebuah hasil yang harus dipilih berdasarkan kriteria yang cukup banyak dari masingmasing alternatif, terlebih metode ini dalam teknik analisisnya terdapat normalisasi dari masing-masing kriteria.

Jadi faktor-faktor yang ada akan menjadi frekuensi yang sama dalam proses perbandingan, hal ini akan menjadikan proses pemilihan Supplier menjadi lebih teliti dan maksimal. Pendapat tersebut didukung oleh (Utomo, 2015) yang menyebutkan bahwa metode ANP relevan untuk dijadikan tools pengambilan keputusan [5] multiple sourcing merupakan satu supplier tidak layak buat memenuhi kebutuhan serta dibutuhkan supplier lain buat memenuhi kebutuhan. Dalam pemilihan supplier terdapat banyak kriteria yang dijadikan bahan acuan. Mulai dari kriteria harga, kualitas, kuantitas dan pengiriman, menjadi bagian bahan pertimbangan yang perlu diamati dalam pemilihan supplier. kriteria seperti harga, kualitas, kuantitas dan pengiriman menjadi kriteria (handiyono 2016) [6].

Proses keputusan pemilihan pemasok termasuk dalam kategori masalah analisis keputusan, dan beberapa metode digunakan dalam proses tersebut, termasuk analytical network procces fungsi dari metode ini adalah untuk dapat melakukan pengukuran pada skala rasio. Dimana anp ini menggunakan basis data kuantitatif yaitu berupa persepsi perorangan dan anp juga berpungsi dapat melakukan pengukuran dalam skala rasio yang digunakan nya yaitu 1 sampai 9 [7]. Dengan menggunakan metode yaitu analytical network process (ANP) dan hayami dapat membantu penelitian memiliki kerangka kelayakan usaha bagi fajar shoes dan pemilihan supplier untuk memperoleh supplier yang diingikan oleh Fajar Shoes. Kontribusi penelitian ini untuk fajar shoes yaitu mengetahui efisiensi usaha sepatu kulit yang dijalankan dan mengetahui nilai tambah sepatu Fajar Shoes dan memberi keputusan supplier yang harus digunakan Fajar Shoes. Dengan menggunakan metode yaitu analytical network process (ANP) dan hayami dapat membantu penelitian memiliki kerangka kelayakan usaha bagi fajar shoes dan pemilihan supplier untuk memperoleh supplier yang diingikan oleh Fajar Shoes. Kontribusi penelitian ini untuk fajar shoes yaitu mengetahui efisiensi usaha sepatu kulit yang dijalankan dan mengetahui nilai tambah sepatu Fajar Shoes dan memberi keputusan supplier yang harus digunakan Fajar Shoes

\section{METODE PENELITIAN}

Penelitian ini mengambil kajian di Fajar Shoes merupakan sebuah usaha UMKM yang terletak di Jln. Ahmad Yani Timur Karangpawitan, Ciparay No.53 dan memproduksi sepatu yang berbahan dasar kulit dan penelitian ini menggunakan metode kualitatif dan kuantitatif, yang dekat dengan penelitian berbasis paradigma ilmiah, dan kualitatif merupakan berbasis gejala untuk mempelajari dan mengidentifikasi. Tujuan dan metode pengolahan data yang digunakan pada penelitian ini adalah sebagai berikut:

1. Melakukan wawancara pada pemilik UMKM fajar shoes dan menentukan kriteria dan alternatif supplier yang digunakan. 
2. Menganalisis efisiensi kelayakan usaha yang dihasilkan Fajar Shoes pada saat sampai penjualan sepatu kulit;

3. Metode yang digunakan adalah metode analytical network process dan hayami.

4. Melakukan penilaian langsung oleh pemilik Fajar Shoes untuk menentukan kriteria yang akan digunakan dan penilaian ini dengan menggunakan software super dicisionss .

5. Pada bagian tahap akhir dilakukan keputusan pemiliihan supplier dengan menggunakan metode analytical network procces.

\section{HASIL DAN PEMBAHASAN}

\section{A. Efisiensi Usaha}

Tabel 1: Nilai Efisiensi Usaha

\begin{tabular}{|c|c|c|}
\hline \multicolumn{2}{|c|}{ Metode } & Nilai \\
\hline \multicolumn{2}{|c|}{$\mathrm{R} / \mathrm{C}$ ratio } & $1,79 \%$ \\
\hline \multicolumn{2}{|c|}{ Profitabilitas } & $38 \%$ \\
\hline \multicolumn{2}{|c|}{ NPV } & Rp. 2.306.000 \\
\hline \multirow{2}{*}{ BEP } & RUPIAH & Rp. 26.137.557 \\
\hline & UNIT & 105 \\
\hline
\end{tabular}

Berdasarkan hasil pengolahan di dapatkan BEP sebesar Rp. 26.137 .557 berdasarkan rupiah dan 105 berdasarkan unit, Perkiraan arus kas atau net present value yang didapatkan UMKM Fajar Shoes selama 1 bulan dengan bunga sebesar 7\% yaitu sebesar Rp. 2.306.000. Karena NPV > 0 (positif), maka bisnis yang dilakukan oleh UMKM Fajar Shoes layak dilaksanakan [8]

\section{B. Nilai tambah}

Tabel 2: Hayami

\begin{tabular}{|c|c|c|c|}
\hline \multicolumn{2}{|r|}{ Variabel } & \multicolumn{2}{|c|}{ Nilai } \\
\hline I. & Output, Input dan Harga & & \\
\hline 1 & produk (pasang/bln) & \multicolumn{2}{|r|}{354} \\
\hline 2 & Bahan baku (lembar/bln) & \multicolumn{2}{|r|}{26} \\
\hline 3 & Jumlah tenaga kerja & \multicolumn{2}{|r|}{6} \\
\hline 4 & Faktor Konversi & \multicolumn{2}{|c|}{13,62} \\
\hline 6 & Harga produk ( $\mathrm{Rp})$ & $\mathrm{Rp}$ & 250.000 \\
\hline 7 & Gajih tenaga kerja (Rp/HOK) & $\mathrm{Rp}$ & 50.000 \\
\hline II & Penerimaan dan Keuntungan & & \\
\hline 8 & Harga Bahan Baku (Rp/lembar) & $\mathrm{Rp}$ & 425.000 \\
\hline 9 & bahan baku lainnya & $\mathrm{Rp}$ & 451.500 \\
\hline 10 & Nilai Output (Rp/bulan) & $\mathrm{Rp}$ & 3.403 .846 \\
\hline \multirow[t]{2}{*}{11} & a. Nilai Tambah $(\mathrm{Rp})$ & $\mathrm{Rp}$ & 2.527 .346 \\
\hline & b. Rasio Nilai Tambah (\%) & \multicolumn{2}{|c|}{$74 \%$} \\
\hline 12 & a. gajih Tenaga Kerja (Rp)/org/bulan & $\mathrm{Rp}$ & 1.400 .000 \\
\hline
\end{tabular}




\begin{tabular}{|c|c|c|c|}
\hline \multicolumn{2}{|r|}{ Variabel } & \multicolumn{2}{|r|}{ Nilai } \\
\hline & b. Pangsa Tenaga Kerja (\%) & & $55 \%$ \\
\hline \multirow[t]{2}{*}{13} & a. profitabilitas $(\mathrm{Rp})$ & $\mathrm{Rp}$ & 1.127 .346 \\
\hline & b. Keuntungan $(\%)$ & & $45 \%$ \\
\hline III & Balas Jasa Pemilik Faktor Produksi & & \\
\hline 14 & $\operatorname{Marjin}(\mathrm{Rp} / \mathrm{bln})$ & $\mathrm{Rp}$ & 2.978 .846 \\
\hline & a. Pendapatan Tenaga Kerja & & $47 \%$ \\
\hline & Variabel & & nilai \\
\hline & b. bahan baku lainnya & & $15 \%$ \\
\hline & Variabel & & nilai \\
\hline & c. Keuntungan Perusahaan /bln & & $38 \%$ \\
\hline
\end{tabular}

dapat dijelaskan bahwa nilai tambah [9] yang dihasilkan dari proses produksi sepatu kulit sebesar Rp. 2.527.346 Nilai tambah ini didapatkan dari hasil pengurangan nilai output dengan biaya bahan baku dan biaya bahan penunjang lainnya \% dengan presentaseu keutungan perusahaan sebesar Rp. 1.127.346 atau 45\%. Sedangkan rasio nilai tambah sebesar $74 \%$ maka artinya $74 \%$ nilai output merupakan nilai tambah yang diperoleh dari pengolahan kulit sampai menjadi sepatu kulit yang hasil akhir nya memiliki nilai jual oleh Faja Shoes [10].

\section{Pemilihan supplier menggunakan metode analytical network procces}

Tabel 3: Penilaian Subkriteria

\begin{tabular}{lc}
\hline \multicolumn{1}{c}{ Subrkiteria } & Incosistency \\
\hline Harga yang murah & 0,09204 \\
\hline $\begin{array}{l}\text { Harga yang sesuai kebutuhan } \\
\text { spesipikasi perusahaan }\end{array}$ & 0,00592 \\
\hline $\begin{array}{l}\text { Harus memberikan potongan atau } \\
\text { diskon apabila pembelian lebih } \\
\text { banyak. }\end{array}$ & 0,01476 \\
\hline Kualitas yang sesuai spesipikasi & 0,02446 \\
\hline Tidak banyak yang cacat & 0,07217 \\
\hline $\begin{array}{l}\text { Memenuhi kebutuhan yang diminta } \\
\text { perusahaan }\end{array}$ & 0,03410 \\
\hline \multicolumn{1}{c}{ Subrkiteria } & Incosistency \\
\hline Cepat dan tepat & 0,03121 \\
\hline
\end{tabular}

Berdasarkan hasil perhitungan mengggunakan supper dicisions dari tiga responden diatas menunjukan bahwa nilai incosistency harus $<0.1$ pada hasil perhitungan menggunakan supper dicisions menunjukan bahwa nilai semua dikategorikan sudah konsisten. Maka dengan itu tidak perlu dilakukanya perbaikan. Pada hasil nilai pembobotan diatas dapat disimpulkan bahwa yang terpilih pertama yaitu subkriteria harga yang murah dengan nilai incosistency 0,09204 kemudian kedua ada subkriteria tidak banyak cacat dengan nilai 0,07217 , subkriteria ketiga yang terpilih ialah memenuhi kebutuhan yang diminta perusahaan dengan nilai incosistency 0,03410 , lalu ke empat ada subkriteria cepat dan tepat dengan nilai 0,03121, kualitas yang sesuai spesifikasi menjadi kelima dengan nilai incosistency 0,02446, subkriteria selanjutnya adalah harus memberikan potongan atau diskon apabila pembelian lebih banyak dengan nilai incosistency 0,00592 dan terakhir ada harga yang sesuai kebutuhan spesipikasi perusahaan dengan nilai incosistency 0,00592. Setelah mendapatkan hasil dari Inconsistency selanjutnya menentukan prioritas perbandingan berpasangan atau bobot kriteria [11]. 
Berdasarkan pemilihan supplier kulit di fajar shoes menggunakan metode ANP untuk menentukan bobot kriteria dengan menggunakan super decissions yang meliputi kriteria harga, kuantitas, kualitas, pengiriman, hasil dari setiap bobot bisa dilihat [12].

Tabel 4: Bobot Kriteria

\begin{tabular}{ccc}
\hline Kriteria & Hasil bobot & Rangking \\
\hline Harga & 0,213027 & 2 \\
\hline Kualitas & 0,283817 & 1 \\
\hline Kuantitas & 0,178586 & 3 \\
\hline Pengiriman & 0,197721 & 4 \\
\hline Jumlah & 1 & \\
\hline
\end{tabular}

Setelah mendapatkan hasil dari inconsistency selanjutnya menentukan prioritas perbandingan berpasangan atau bobot kriteria [11]. Hasil dari prioritas perbandingan berpasangan di sajikan pada gambar.

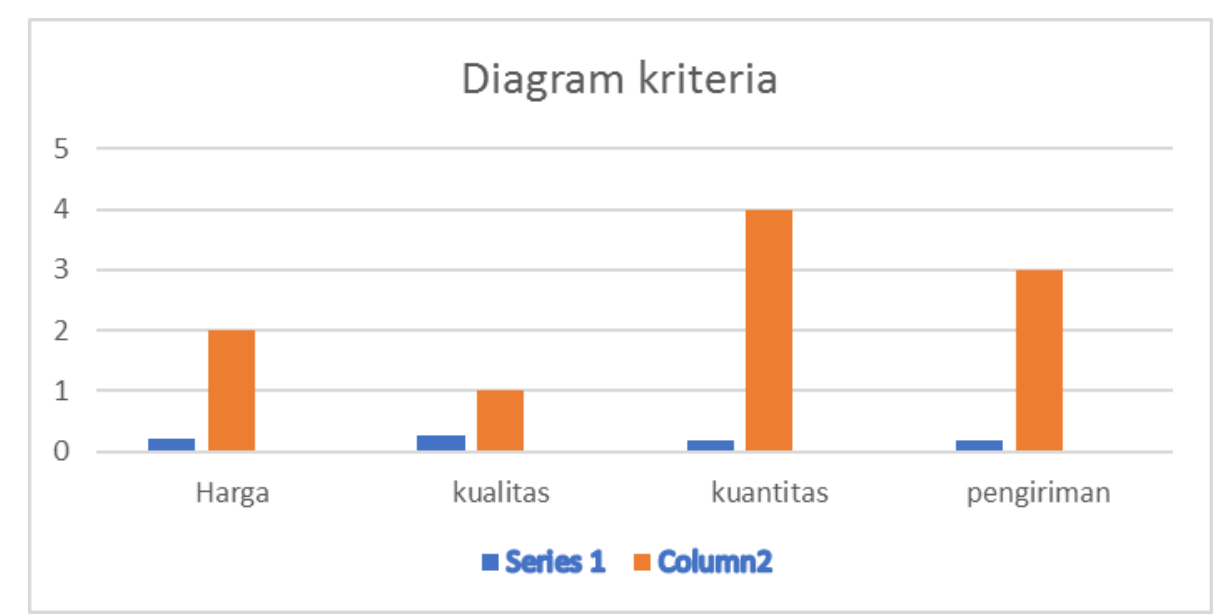

Gambar 1: diagram bobot kriteria

Berdasarkan diagram diatas menjelaskan bahwa kriteria kualitas menjadi kriteria yang berada diposisi pertama dalam pemilihan supplier di fajar shoes artinya bahwa kualitas bahan baku kulit yang bagus dan sesuai dengan spesifikasi yang sudah diterapkan merupakan hal yang penting untuk mempertahankan perusahaan dalam menetapkan dimana kriteria kualitas memiliki nilai bobot kriteria 0,283817. Dan kriteria kedua diperoleh dengan kriteria harga merupakan yang ditetapkan oleh supplier [13] merupakan hal yang penting juga bagi perusahaan untuk mempertahankan konsumen dengann memiliki nilai incosistency 0,213027 Kriteria kuantitas dengan nilai 0,178586 yang artinya bahwa kuantitas diperlukan oleh fajar shoes karena untuk memenuhi kebutuhan apabila terjadi pemesanan sepatu overload dan supplier harus memenuhi kulit untuk bahan baku sepatu kulit di fajar shoes dan kriteria yang ke 4 yaitu kriteria pengiriman, menjadi kriteria yang digunakan dalam menentukan supplier terbaik, meskipun tidak terlalu berpengaruh karena pengiriman hanya memiliki nilai bobot 0,197721 kriteria jika dilihat dari hasil nilai incosistency sub kriteria pengiriman ketepatan jumlah pengiriman dan pengiriman tepat waktu. 


\section{Analisis Pemilihan Supplier}

Tabel 5: Pemilihan Supplier

\begin{tabular}{ccc}
\hline Supplier & Hasil Bobot & Rangking \\
\hline Abadi Leather & 0.069658 & 2 \\
\hline Bongsor Leather & 0.140892 & 1 \\
\hline Perkasa Leather & 0.031954 & 3 \\
\hline
\end{tabular}

Setelah selesai melakukan perhitungan terdapat alternatif yang terpilih adalah seperti penjelasaan pada gambar 3.2

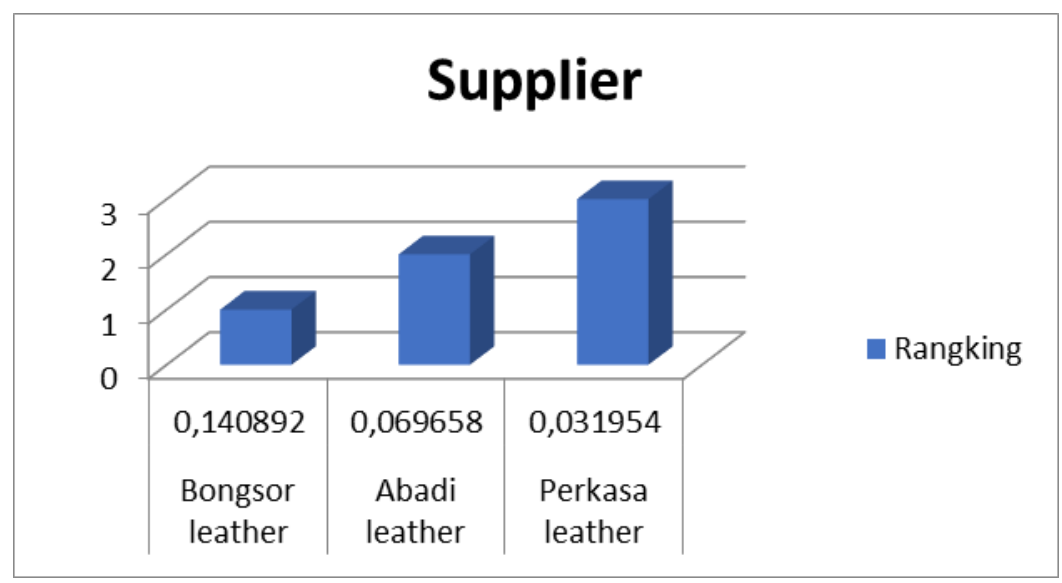

Gambar 2: Keputusan Supplier

Hasil rekapitulasi untuk keputusan pemilihan supplier bahwa bongsor leather menjadi supplier yang terpilih pertama dan memiliki nilai terbesar yaitu 0,140892 perusahaan ini lebih mengutamakan kualitas yang utama dari pihak supplier agar baku kulit yang bagus dan sesuai dengan spesifikasi merupakan hal yang penting untuk mempertahankan perusahaan dalam menetapkan konsumen. Kemudian supplier kedua yaitu abadi leather yang memiliki nilai 0,069658 dan ketiga ada perkasa leather dengan nilai 0,031954.

\section{V.KESIMPULAN}

Efisiensi kelayakan usaha pada sepatu kulit ini sampai penjualan bahwa profitabilitas yang didapatkan yaitu sebesar 38\%. Dimana jika profitabilitas $>0 \%$ maka usaha yang dijalankan sudah menguntungkan. Berdasarkan hasil pengolahan, $\mathrm{R} / \mathrm{C}$ racio yang didapatkan fajar shoes yaitu sebesar 1.79. Dimana R/C Racio > 1, maka dinyatakan usaha yang dijalankan Fajas Shoes sudah efisien. Net present value yang didapatkan Fajar Shoes pada 1 periode pertama dengan suku bunga $7 \%$ yaitu sebesar Rp.2.306.000. karena NPV > 0 (positiv) maka bisnis yang dijalankan perusahaan Fajar Shoes sudah layak dilaksanakan. Berdasarkan hasil pengolahan, didapatkannila BEP berdasarkan rupiah sebesar Rp.26.137.557 dan berdasrakan unit sebesar 105 pasang. sedangkan rasio nilai tambah sebesar $74 \%$ maka artinya $74 \%$ dari nilai output merupakan nilai tambah yang diperoleh dari pengolahan kulit sampai menjadi sepatu kulit yang hasil akhir nya memiliki nilai jual oleh Faja Shoes.

Dari ke empat kriteria yang digunakan Fajar Shoes yang terpilih pertama yaitu ada kriteria kulitas dengan nilai bobot 0,283817 , kedua ada kriteria harga dengan nilai bobot 0,213027 , ketiga ada kriteria kuantitas dengan nilai bobot 0,178586 dan yang ke empat ada kriteria pengiriman yang memiliki nilai bobot $0,197721 \mathrm{Hal}$ ini 
menunjukan bahwa kriteria kualitas merupakan kriteria yang paling penting dalam pemilihan supplier kulit terbaik di UMKM Fajar Shoes. Berdasarkan hasil pembobotan dengan menggunakan analytical network procces (ANP) dibantu dengan software supper diccision yang terpilih sebagai supplier pertama yaitu bongsor leather yang memiliki nilai bobot 0.140892 .

\section{DAFTAR PUSTAKA}

[1] fitri, "Program Studi Teknik Industri," Anal. supply Chain Manag. pada batik tulis garutan menggunakan gren scor menggunakan Metod. anp, vol. 2, no. 2, p. 9, 2015.

[2] R. Y. H. Saputra, N. Nazir, "dengan lebih fokus kepada strategi SO (," vol. 2, no. 2, pp. 3-14, 2016.

[3] N. Nurfadilah, A. Armaini, and H. Yetti, "Analisis Efisiensi Dan Nilai Tambah Agroindustri Tahu di Kota Pekanbaru," J. Online Mhs. Fak. Pertan. Univ. Riau, vol. 1, no. 1, pp. 1-12, 2017.

[4] I. A. Sandy and H. Fathurahman, "Penggunaan Metode Analytic Network Process (ANP) dalam Pemilihan Supplier Bahan Baku Kertas pada PT Mangle Panglipur," J. Rekayasa Sist. Ind., vol. 2, no. 1, pp. 32-39, 2018, doi: 10.26593/jrsi.v2i1.334.32-39.

[5] Sharoudi, “Analisa Pemilihan Supplier Menggunakan Metode ANP Dan TOPSIS Untuk,” J. Tek. Ind., vol. 2, no. 2, p. 7, 2016.

[6] M. Amyriki, M. F. F. Mu'amar, and S. Hastuti, "Analisis Pemilihan Supplier Gabah dengan Metode Analitycal Network Proces (ANP) (Studi kasus: Gudang Baru Bulog Gunung Gedangan, Mojokerto)," Rekayasa, vol. 9, no. 1, p. 1, 2016, doi: 10.21107/rekayasa.v9i1.3322.

[7] D. Nurlaila, D. Supriyadi, and A. E. Amalia, "Penerapan Metode Analytic Network Process (ANP) Untuk Pendukung Keputusan Pemilihan Tema Tugas Akhir (Studi Kasus: Program Studi S1 Informatika ST3 Telkom)," J. Inform. J. Pengemb. IT Poltek Tegal, vol. 2, no. 2, pp. 63-68, 2017, [Online]. Available: http://ejournal.poltektegal.ac.id/index.php/informatika/article/view/511.

[8] A. R. Pamungkassari, M. Marimin, and I. Yuliasih, "Analisis Kinerja, Nilai Tambah Dan Mitigasi Risiko Rantai Pasok Agroindustri Bawang Merah,” J. Teknol. Ind. Pertan., vol. 28, no. 1, pp. 61-74, 2018, doi: 10.24961/j.tek.ind.pert.2018.28.1.61.

[9] Ane novianty, "profitabilitas dan titik impas agroindustri gula kelapa di kabupaten pangandaran dan efisiensi usaha," vol. 22, no. 2, p. 27, 2019.

[10] J. Sisingamangaraja, K. M. Agung, and K. Baru, "Modifikasi Metode Hayami Untuk Perhitungan Nilai Tambah Pada Rantai Pasok Agroindustri Kelapa Sawit Modification of Hayami'S Value Added Method for the Palm Oil Agroindustry Supply Chain," J. Teknol. Ind. Pertan., vol. 22, no. 1, pp. 22 31, 2016.

[11] Govindaraju, "Pengambilan Keputusan Pemilihan Pemasok di Perusahaan Manufaktur dengan Metode Fuzzy ANP," J. Manaj. Teknol., vol. 16, no. 1, pp. 1-16, 2017, doi: 10.12695/jmt.2017.16.1.1.

[12] A. F. Falatehan, "Analytical Hierarchy Process (AHP) Teknik Pengambilan Keputusan Untuk Pembangunan Daerah,” pp. 17-24, 2016.

[13] M. Jannah, M. Fakhry, and Rakhmawati, "Pengambilan Keputusan Untuk Pemilihan Supplier Bahan Baku Dengan Pendekatan Analytic Hierarchy Processdi Pr Pahala Sidoarjo," Agrointek, vol. Vol. 5, no. 2, pp. 88-97, 2016. 